\title{
The Effect of Various Training on the Expression of the 5'amp- Activated Protein Kinase A2 and Glucose Transporter - 4 in Type-2 Diabetes Mellitus Rat
}

\author{
Rahmi Rahmi ${ }^{1}$, Yetty Machrina* (i) ${ }^{2 *}$ Zulham Yamamoto ${ }^{3}$ (D) \\ ${ }^{1}$ Department of Biomedical Sciences, Faculty of Medicine, Universitas Sumatera Utara, Medan, Indonesia; ${ }^{2}$ Department of \\ Physiology, Faculty of Medicine, Universitas Sumatera Utara, Medan, Indonesia; ${ }^{3}$ Department of Histology, Faculty of Medicine, \\ Universitas Sumatera Utara, Medan, Indonesia
}

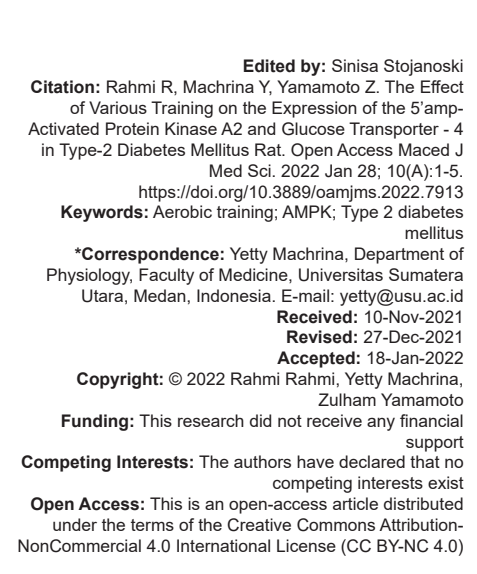

NonCommercial 4.0 International License (CC BY-NC 4.0)

\begin{abstract}
BACKGROUND: Exercise is the main pillar in Type 2 Diabetes Mellitus (T2DM) management. The mechanism of glucose uptake mediated by exercise is different from insulin, and this mechanism is not disturbed in T2DM. One of the mechanisms is through the activation of 5'AMP-activated protein kinase (AMPK). AMPK also regulates the glucose transporter 4 (GLUT4) expression. Effect various types of exercise to AMPK $\alpha 2$ and GLUT-4 of the skeleta muscle still limited.
\end{abstract}

AIM: This study aims to determine the effect of various physical training on the expression of Ampk $\alpha 2$ and Glut 4 in skeletal muscle of T2DM rats.

METHODS: This study used stored skeletal muscles of 25 T2DM Wistar rats. Previously, the rats were divided into groups of K1 (control, not given exercise), K2 (moderate continuous training), K3 (severe continuous training), K4 (slow interval training), and K5 (fast interval training). Running on a treadmill frequency 3 times a week for 8 weeks. The relative expression of Ampk $\alpha 2$ and Glut 4 were assessed using Real Time-PCR and were compared among the groups using the Livak formula.

RESULTS: Moderate intensity continuous training increased Ampk $\alpha 2$ and Glut 4 expression by 1.45 and 2.39 times, respectively. Severe intensity continuous training increased the expression of Ampk $\alpha 2$ and Glut 4 by 1.55 and 2.56 times, respectively. Slow interval training increased the expression of Ampk $\alpha 2$ and Glut 4 by 4.41 and 3.76 times, respectively. The expression of Ampk $\alpha 2$ and Glut4 in fast interval training was 4.56 and 4.79 times more than control.

CONCLUSION: Continuous and interval training increase Ampk $\alpha 2$ and Glut 4 expression. The fast interval training showed the highest expression of Ampk $\alpha 2$ and Glut 4.

\section{Introduction}

The prevalence of Diabetes Mellitus Type-2 (T2DM) in the world continues to increase every year [1]. Indonesia also experienced an increase in prevalence from $6.9 \%$ in 2013 to $8.5 \%$ in 2018 [2]. One of the reasons for this increase is the lack of physical activity. Physical inactivity can reduce insulin sensitivity due to mitochondrial dysfunction, especially skeletal muscle because the skeletal muscle was one of the organs with large amount of insulin receptor. Insensitivity of insulin receptor, lead to glucose uptake impairment. As the compensation of energy insufficiency in cell, hepar will produce gluconeogenesis [3], [4].

Exercise is one of the main pillars of managing T2DM [5]. Exercise and muscle contraction stimulate glucose uptake through a different mechanism than insulin-mediated one [6]. In patients with T2DM, insulin-mediated glucose intake is impaired although exercise-mediated glucose uptake is normal or nearly normal [7]. The activation of 5'AMP-activated protein kinase (AMPK) is one of the insulin-independent mechanisms that is mediated by exercise. AMPK is a heterotrimeric protein kinase consisting of $\alpha, \beta$, and $\gamma$ subunits, encoded by different genes $(\alpha 1, \alpha 2, \beta 1, \beta 2$, $\gamma 1, \gamma 2$, and $\gamma 3$ ). AMPK is activated by energy stress in response to an increase in ATP consumption or a decrease in ATP production, in the form of a low ratio of ATP to AMP and ADP [8]. When exercising, the amount of ADP and AMP increases rapidly while ATP decreases slightly, activating AMPK and stimulating glucose uptake by translating GLUT4 to the plasma membrane [9], [10].

AMPK also regulates GLUT4 expression [10]. This is supported by the finding that exercise, through AMPK activation, can increase GLUT4 expression in skeletal muscle [11], [12], [13]. Increased expression of skeletal muscle GLUT4 may improve blood sugar control in T2DM [14]. During exercise, only $\alpha 2 \beta 2 \gamma 1$ and $\alpha 2 \beta 2 \gamma 3$ complexes are activated and cause 
muscle glucose uptake [15]. Exercise activates $\alpha 2$ subunits more than $\alpha 1$ because $\alpha 2$ subunit activation is more dependent on AMP concentration [16]. Exercise, through AMPK $\alpha 2$ mediation, could increase the binding of the transcription factor GLUT4 to the promoter [17].

The most effective exercise strategy in T2DM has not been established [18]. The American Diabetes Association (2019) recommends moderate to severe aerobic exercise [19]. Aerobic exercise comprises continuous and interval training [20], both methods are effective in improving glycemic control [21]. Continuous training is more often recommended as an aerobic exercise option [22]. However, doing high-intensity continuous training for a long duration can be risky and difficult to do in patients with chronic diseases such as T2DM [21]. Interval training can be an alternative since it induces cardiometabolic adaptations that are similar to continuous training and has superior benefits compared to continuous training in T2DM patients [23].

The effect of moderate-to-severe intensity continuous and interval training on AMPK and GLUT4 expression in T2DM is not well known. This study will examine the effect of various training models, moderate-intensity continuous training, severe intensity continuous training, slow interval training, and fast interval training on the expression of Ampk $\alpha 2$ and Glut4 in the Wistar rat T2DM model.

\section{Methods}

\section{Animals}

The ethical clearance for this study was obtained from The Research Ethics Committee, Faculty of Medicine, Universitas Sumatera Utara (No. 562/KEP/USU/2020). This study used stored muscle tissues of male white Wistar rats which have been grouped into 25 T2DM rats [24]. The preparation of experimental animal models was modified from the previous study [25]. The rats were placed in a cage at room temperature, with a lightdark cycle of $12 / 12 \mathrm{~h}$. The T2DM model was carried out by providing a high-fat diet with a composition of $41 \%$ fat, $41 \%$ carbohydrates, and $18 \%$ protein for 5 weeks and injected $30 \mathrm{mg} / \mathrm{kgBW}$ dan $45 \mathrm{mg} / \mathrm{kgBW}$ of streptozotocin intraperitonial. This procedure was followed Machrina et al. (2018) that was modified from Zhang et al. protocol. Rats with fasting glucose levels were $>200 \mathrm{mg} / \mathrm{dL}$ are grouped as T2DM rats while insulin resistance was determined using HOMA-IR values $>6.5$. At the end of the study, all the animals were sacrified under sedation. Gastrocnemius from all groups was taken and keep in RNA later [24].

\section{Aerobic training}

T2DM rats were divided into five groups, namely, K1: the sedentary group (not treated) as the control group; K2: group with moderate-intensity continuous training: running on a treadmill with a running speed of $20 \mathrm{~m} / \mathrm{min}$, for $30 \mathrm{~min}$; K3: group with severe intensity continuous training: running on a treadmill with a running speed of $24-33 \mathrm{~m} / \mathrm{min}$, for $30 \mathrm{~min}$; K4: group with slow interval training: running on a treadmill with a running speed of $20 \mathrm{~m} / \mathrm{min}, 10$ repetition sessions, with a duration of $2 \mathrm{~min} / \mathrm{session}$ interspersed with rest for $1 \mathrm{~min}(20 \mathrm{~m} / \mathrm{min}, 10 \times 2 \mathrm{~min}$, rest $1 \mathrm{~min})$; K5: group with fast interval training: running on a treadmill with a running speed of $30 \mathrm{~m} / \mathrm{min}, 15$ repetition sessions with a duration of $30 \mathrm{~s} /$ session interspersed with a rest for $1 \mathrm{~min}(30 \mathrm{~m} / \mathrm{min}, 15 \times 30 \mathrm{~s}$, rest $1 \mathrm{~min})$. Physical training in the $\mathrm{K} 2, \mathrm{~K} 3, \mathrm{~K} 4$, and $\mathrm{K} 5$ was carried out for 8 weeks, three times a week [24].

\section{Real time-PCR}

RNA was extracted from $30 \mathrm{mg}$ of the muscles using commercial kit (Tiangen Simple Total RNA Kit, Tiangen, China). The Nanodrop ND-1000 spectrophotometer (Thermo Fisher Scientific, Newington, $\mathrm{NH}$, USA) was applied to measure the concentration and purity of extracted RNA. RNA samples were reverse-transcribed using ReadyScript cDNA Synthesis Mix (Sigma Aldrich, Darmstadt, Germany). Specific primers were used in this study for Ampk $\alpha 2$ and Glut4 and gene expression was normalized using $\beta$-actin as a housekeeping gene (Table 1). Primers were purchased from Macrogen, Seoul, South Korea.

Table 1: Primers sequences

\begin{tabular}{ll}
\hline Gene & Primer \\
\hline$\beta$ actin & F 5'-AGGCCCCTCTGAACCCTAAG-3' \\
Ampk $\alpha 2$ & R 5'-ATGTCACGCACGATTTCCCT-3' \\
& F 5'-GATCGGACACTACGTGCTGG-3' \\
Glut4 & R 5'- GACAGTAGTCCACGGCAGAC-3' \\
& F 5'- GGCCGGGACACTATACCCTA-3' \\
& R 5'- GGAGGAATCATGCCACCCA-3' \\
\hline
\end{tabular}

A total of $20 \mu \mathrm{L}$ real time-PCR reactions were made up as follows in a 36 well plate; 100 ng of cDNA in $6,4 \mu \mathrm{l}$ of Rnase free $d d^{2} \mathrm{H}_{2} \mathrm{O}, 10 \mu \mathrm{L}$ of SensiFast SYBR No-Rox Mix (Bioline Reagents Ltd. the United Kingdom) and $0.8 \mu \mathrm{L}$ of both forward and reverse primers at 100 $\mu \mathrm{M}$ concentrations. The amplification process was performed using RotorGene (Qiagen, Germany), which was programmed to perform the following steps; 2 min hold at $95^{\circ} \mathrm{C}$, and then 40 cycles at $95^{\circ} \mathrm{C}$ for $5 \mathrm{~s}$ and $60^{\circ} \mathrm{C}$ for $20 \mathrm{~s}$. The mRNA expression was represented using the $\mathrm{Rq}$ which is normalised to the control group or $\mathrm{Rq}=2^{-\Delta \Delta \mathrm{Ct}}(\Delta \mathrm{Ct}=\mathrm{Ct}[$ target $]-\mathrm{Ct}[\beta$-actin $] ; \Delta \Delta \mathrm{Ct}=\Delta \mathrm{Ct}$ [sample] $-\Delta \mathrm{Ct}$ [control]) [26].

\section{Statistical analysis}

Effect aerobic training to fasting blood glucose in treatment groups was analyzed with paired $t$-test. To 
compare the cycling threshold from Ampk $\alpha 2$ and Glut4 gen expression difference among group, we analyzed data with One Way ANOVA. Relative expression of Ampk $\alpha 2$ and Glut4 in each group was determined by livask formula.

Table 2: The comparation of $\Delta \mathrm{Ct} A m p k \alpha 2$ and $\Delta \mathrm{Ct}$ Glut4 among group

\begin{tabular}{|c|c|c|}
\hline Groups & $\Delta \operatorname{Ct} A m p k \alpha 2$ & $\Delta \mathrm{Ct}$ Glut4 \\
\hline & $X \pm S D$ & $X \pm S D$ \\
\hline K1 & $1.78 \pm 3.75$ & $4.72 \pm 5.00$ \\
\hline K2 & $1.24 \pm 1.37$ & $3.46 \pm 1.30$ \\
\hline K3 & $1.15 \pm 1.37$ & $3.36 \pm 2.85$ \\
\hline K4 & $0.36 \pm 3.03$ & $2.80 \pm 3.13$ \\
\hline K5 & $0.41 \pm 4.85$ & $2.46 \pm 3.37$ \\
\hline
\end{tabular}

\section{Results}

Aerobic training for 8 weeks significant reduce fasting in all groups (Table 3). Average of cycling threshold (Ct) for AMPK A2 and GLUT-4 in treatment groups were lower than control group (Table 2). Cycling threshold value was inverse to mRNA gene expression, which mean lower $\mathrm{Ct}$, higher mRNA gene expression.There was an increase in gene expression of Ampk $\alpha 2$ and Glut4 after 8 weeks of training. Moderate intensity continuous training increased Ampk $\alpha 2$ expression by 1.45 times and Glut 4 expression 2.39 times. Severe intensity continuous training increased the expression of Ampk $\alpha 2$ by 1.55 times and the expression of Glut 4 by 2.56 times. The highest expression of Ampk $\alpha 2$ and Glut 4 was shown in the fast interval training group. The expression of Ampk $\alpha 2$ and Glut 4 were 4.56 and 4.79 fold higher than the control group, respectively (Figure 1 and Figure 2).

\section{Discussion}

The results of this study indicated that there was an increase in Ampk $\alpha 2$ expression in the four groups that were given physical training. The interval training group experienced an increase in Ampk $\alpha 2$ expression higher than the continuous exercise group. The highest increase in the expression was found in the group with fast interval training. In addition, exercise with a higher intensity will further increase the expression of Ampk $\alpha 2$. The results of this study are in line with Cao et al. Cao et al., (2012) reported that swimming exercise in T2DM rats model for 8 weeks increased the expression of Ampk $\alpha 2$ protein 1.5 times compared to rats that were not given exercise [13]. Brandt et al., (2010) also reported that swimming exercise for 4 weeks increased Ampk $\alpha 2$ expression by $43 \%$ in insulin resistance-induced rats [27].

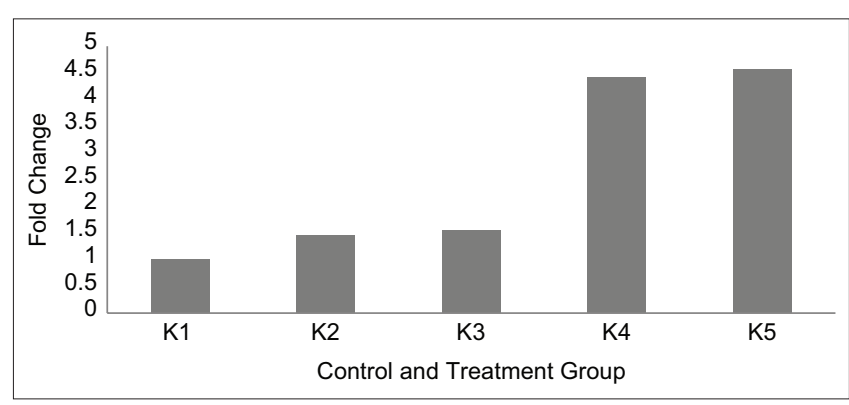

Figure 1: Relative Ampk $\alpha 2$ Expression in Each Group. Livask formula $=2^{-\Delta \Delta C t}$. K2 expressed Ampk $\alpha 21.45$ fold than K1; $K 3$ expressed 1.55 fold than $K 1 ; K 4$ expressed 4.41 fold than $K 1$; $K 5$ expressed 4.56 fold than $K 1$

Table 3: Fasting Blood Glucose before and after treatment among group

\begin{tabular}{|c|c|c|c|c|}
\hline \multirow[t]{2}{*}{ Group } & \multicolumn{2}{|c|}{ Fasting Blood Glucose (mg/dl) } & \multirow{2}{*}{$\begin{array}{l}\mathrm{FFBG} \\
\text { (After-Before) } \\
\end{array}$} & \multirow[t]{2}{*}{$\mathrm{p}$ value } \\
\hline & Before treatment & After treatment & & \\
\hline$\overline{\mathrm{K} 1}$ & $474.8 \pm 24.9$ & $214.9 \pm 5.7$ & & \\
\hline K2 & $339 \pm 103.7$ & $191.6 \pm 5.4$ & -147.4 & 0.014 \\
\hline K3 & $396.8 \pm 25.7$ & $198.2 \pm 75.0$ & -198.6 & $0.009^{*}$ \\
\hline K4 & $452.6 \pm 31.3$ & $227.2 \pm 87.8$ & -225.4 & $0.001^{*}$ \\
\hline K5 & $451.2 \pm 83.2$ & $259 \pm 125.0$ & -192.2 & $0.006^{*}$ \\
\hline
\end{tabular}

During exercise, repeated muscle contractions cause ATP to be consumed faster than it is synthesized. This results in an increase in ADP, which is followed by an increase in AMP due to the action of the adenylate kinase enzyme in the cytosol. This enzyme converts two ADP molecules into one ATP molecule and one AMP molecule. An increase in the AMP/ATP ratio causes AMPK activation and alters the anabolic and catabolic rates to restore intracellular ATP [28]. Apart from muscle tissue, AMPK also plays a critical role in controlling glucose production in the liver. AMPK activation in the liver mediates the hypoglycemic effect of adiponectin [29]. Previous study showed that moderate-intensity continuous training, severe intensity continuous training, slow interval training, and fast interval training increase the expression of Ampk $\alpha 1$ in the liver and decrease fasting glucose levels in T2DM rats [30].

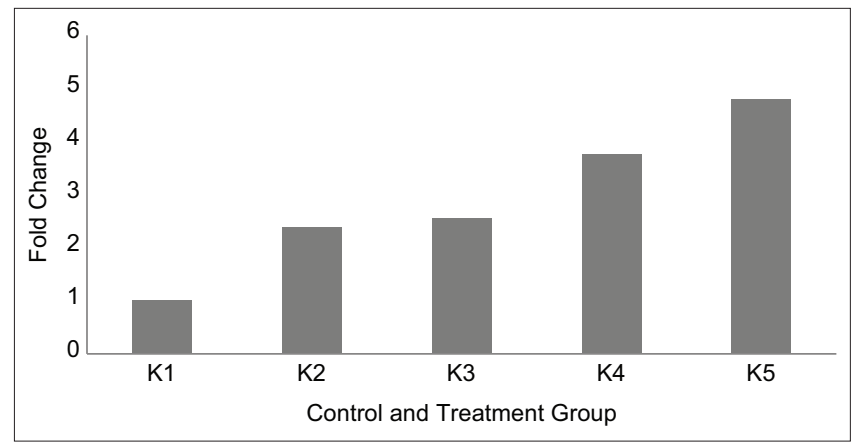

Figure 2: Relative Glut4 Expression in Each Group. Livask formula $=2^{-\Delta \Delta C t} . K 2$ expressed Ampk $\alpha 22.39$ fold than K1; $K 3$ expressed 2.56 fold than $K 1 ; K 4$ expressed 3.76 fold than $K 1$; $K 5$ expressed 4.79 fold than $K 1$

AMPK activation depends on the exercise intensity. AMPK activation requires a high enough intensity, which is above $50 \% \mathrm{VO}_{2} \max$ [31]. Greater ATP turnover occurs in greater intensity exercise. ADP 
and AMP levels increase along with increasing exercise intensity and trigger AMPK activation [28].

The change in substrate use or mobilization for interval training is steeper than for continuous training. Plasma lactate and glucose levels during interval training are lower than during continuous training. This difference explains the greater energy requirements of interval training compared to continuous training. This results in a significant increase in the AMP/ATP ratio [32]. In addition, the exercise-rest pattern on interval training also has an effect. AMPK activity was 2.9 times higher when the intensity training session was punctuated by rest intervals, compared to when the exercise was done continuously for $30 \mathrm{~min}$ [33].

The increase in Glut4 expression in this study was in line with the results of the increase in Ampk $\alpha 2$ expression. T2DM is characterized by insulin resistance, a condition in which cells are unable to respond to insulin, especially in the liver, skeletal muscle, and fat tissue [34]. There are several mechanisms of insulin resistance. One of them is due to a decrease in the number of insulin receptors and their catalytic activity. This change causes a decrease in glucose uptake in the muscles [35]. Previous study showed that moderate-intensity continuous training, severe intensity continuous training, slow interval training, and fast interval training in T2DM rats improve insulin receptor distribution and the highest percentage increase in the distribution is in the fast interval group. The increase in the distribution of insulin receptors was followed by a decrease in insulin resistance [24].

Insulin resistance is also associated with disturbances in GLUT4 expression.[35] The amount of GLUT4 in skeletal muscle is mainly regulated at the transcription level. GLUT4 transcription is mediated by a transcription factor, namely, myocyte enhancer factor 2 (MEF2) [36]. In the resting state, MEF2 is physically associated with the transcription repressor histone deacetylase 5 (HDAC5) [11].

There are two enzymes that can phosphorylate HDAC5, namely Calmodulindependent Protein Kinase (CaMK) and AMPK [6]. During the contraction during exercise, each wave of depolarization will remove $\mathrm{Ca}$ from the reticulum sarcoplasm and increase the concentration of $\mathrm{Ca}$ in the cytosol and activate CaMK [37]. Both CaMK and AMPK which are activated during exercise can phosphorylate HDAC5 so that HDAC5 leaves the nucleus and the MEF2/HDAC5 complex dissociates. The dissociation of the MEF2/HDAC5 complex causes MEF2 binding to PGC-1 $\alpha$ and increase GLUT4 expression [6], [38]. An important adaptation of exercise is increased GLUT4 expression in skeletal muscle, increased capacity for glucose transport, and better systemic control [39]. Previous study showed that moderate-intensity continuous exercise, severe intensity continuous exercise, slow interval training, and fast interval training in T2DM rats significantly reduces fasting blood sugar levels compared to the sedentary group [40].

\section{Conclusion}

Moderate-intensity continuous training, severe intensity continuous training, slow interval training, and fast interval training increased the Ampk $\alpha 2$ and Glut4 expression. The highest increase in expression was found in the fast interval training group.

\section{References}

1. Saeedi P, Petersohn I, Salpea P, Malanda B, Karuranga S, Unwin N, et al. Global and regional diabetes prevalence estimates for 2019 and projections for 2030 and 2045: Results from the International Diabetes Federation Diabetes Atlas, $9^{\text {th }}$ edition. Diabetes Res Clin Pract. 2019;157:107843. https:// doi.org/10.1016/j.diabres.2019.107843

PMid:31518657

2. Ditjen Kesehatan Masyarakat Kementrian Kesehatan Kementrian Kesehatan Republik Indonesia, Hasil Riskesdas Tahun 2018; 2020. Available from: https://www.kesmas. kemkes.go.id/assets/upload/dir_519d41d8cd98f00/files/Hasilriskesdas-2018_1274.pdf [Last accessed on 2020 Nov 20].

3. Neill HM. AMPK and exercise: Glucose uptake and insulin sensitivity. Diabetes Metab J. 2013;37(1):1-21. https://doi. org/10.4093/dmj.2013.37.1.1

PMid:23441028

4. Sharabi K, Tavares CD, Rines AK, Puigserver P. Molecular pathophysiology of hepatic glucose production. MolAspects Med. 2015;46:21-33. https://doi.org/10.1016/j.mam.2015.09.003 PMid:26549348

5. PERKENI. In: Soelistijo SA, Novida $H$, editors. Konsensus Pengelolaan dan Pencegahan Diabetes Melitus Tipe 2 di Indonesia 2015. Jakarta: PB PERKENI; 2015. p. 10-61.

6. Richter EA, Hargreaves M. Exercise, GLUT4, and skeletal muscle glucose uptake. Physiol Rev. 2013;93(3):993-1017. PMid:23899560

7. Stanford KI, Goodyear LJ. Exercise and Type 2 diabetes: Molecular mechanisms regulating glucose uptake in skeletal muscle. Adv Physiol Educ. 2014;38:308-14. https://doi. org/10.1152/advan.00080.2014 PMid:25434013

8. Yan Y, Zhou XE, Xu HE, Melcher K. Structure and physiological regulation of AMPK. Int J Mol Sci. 2018;19(11):3534. https://doi. org/10.3390/ijms19113534

\section{PMid:30423971}

9. Richter EA, Ruderman NB. AMPK and the biochemistry of exercise: Implications for human health and disease. Biochem J. 2010;418(2):261-75. https://doi.org/10.1042/BJ20082055 PMid:19196246

10. Pereira RM, Sanchez A. Molecular mechanisms of glucose uptake in skeletal muscle at rest and in response to exercise. Moritz Rio Carlo. 2017;23:1-8

11. Mcgee SL, van Denderen BJ, Howlett KF, Mollica J, Schertzer JD, 
Kemp BE, et al. AMP-activated protein kinase regulates GLUT4 transcription by phosphorylating histone deacetylase 5. Clin Exp Pharmacol Physiol. 2008;57:860-7.

12. Hussey SE, McGee SL, Garnham A, Wentworth JM, Jeukendrup AE, Hargreaves $M$. Research letter in patients with Type 2 diabetes research letter. Diabetes Obes Metab. 2011;13(10):959-62. https://doi. org/10.1111/j.1463-1326.2011.01426.x

PMid:21615668

13. Cao S, Li B, Yi X, Chang B, Zhu B, Lian Z, et al. Effects of exercise on AMPK signaling and downstream components to PI3K in rat with Type 2 diabetes. PLoS One. 2012;7(12):e51709. https://doi.org/10.1371/journal.pone.0051709 PMid:23272147

14. Hansen JS, Zhao X, Irmler M, Liu X, Hoene M, Scheler M, et al. Type 2 diabetes alters metabolic and transcriptional signatures of glucose and amino acid metabolism during exercise and recovery. Diabetologia. 2015;58(8):1845-54.

15. Lantier L, Fentz J, Mounier R, Leclerc J, Treebak JT, Pehmøller C, et al. AMPK controls exercise endurance, mitochondrial oxidative capacity, and skeletal muscle integrity. FASEB J. 2014;28(7):3211-24. https://doi.org/10.1096/fj.14-250449 PMid:24652947

16. Jørgensen SB, Jensen TE, Richter EA. Role of AMPK in skeletal muscle gene adaptation in relation to exercise. Appl Physiol Nutr Metab. 2007;32(5):904-11. https://doi.org/10.1139/H07-079 PMid: 18059615

17. Gong $\mathrm{H}$, Xie J, Zhang N, Yao L, Zhang Y. MEF2A binding to the Glut4 promoter occurs via an AMPK $\alpha$ 2-dependent mechanism. Med Sci Sports Exerc. 2011;43(8):1441-50. https:// doi.org/10.1249/MSS.0b013e31820f6093

PMid:21233771

18. Francois ME, Little JP. Effectiveness and safety of high-intensity interval training in patients with Type 2 diabetes. Diabetes Spectr. 2015;28(1):39-44. https://doi.org/10.2337/diaspect.28.1.39 PMid:25717277

19. American Diabetes Association. Lifestyle Management: Standards of Medical Care in Diabetes 2019. Diabetes Care. 2019;42:46-60.

20. Spanoudaki S. Interval versus continuous training. J Sports Med Doping Stud. 2011;1(1):4172.

21. Mitranun W, Deerochanawong C, Tanaka H, Suksom D. Continuous vs interval training on glycemic control and macro- and microvascular reactivity in Type 2 diabetic patients. Scand J Med Sci Sport. 2014;24(2):69-76. https://doi.org/10.1111/sms.12112 PMid:24102912

22. Álvarez C, Ramirez-campillo R, Alvarez C, Mancilla R, Ciolac EG. Low-volume high-intensity interval training as a therapy for Type 2 diabetes. Int J Sport Med. 2016;3:1-8. https:// doi.org/10.1055/s-0042-104935 PMid:27259099

23. De Nardi AT, Tolves T, Lenzi TL, Signori LU, da Silva AM. High-intensity interval training versus continuous training on physiological and metabolic variables in prediabetes and Type 2 diabetes: A meta-analysis. Diabetes Res Clin Pract. 2018;137:149-59. https://doi.org/10.1016/j.diabres.2017.12.017 PMid:29329778

24. Machrina $Y$, Damanik HA, Purba A, Lindarto D. Effect various type of exercise to Insr gene expression, skeletal muscle insulin receptor and insulin resistance on diabetes mellitus type-2 model rats. Int J Health Sci. 2018;6(4):50-6.

25. Zhang M, Lv XY, Li J, Xu ZG, Chen L. The characterization of high-fat diet and multiple low-dose streptozotocin induced Type 2 diabetes rat model. Exp Diabetes Res. 2008;2008:704045. https://doi.org/10.1155/2008/70404

PMid:19132099
26. Livak KJ, Schmittgen TD. Analysis of relative gene expression data using real-time quantitative PCR and the 2(-delta delta $C(T)$ ) method. Methods. 2001;25(4):402-8. https://doi. org/10.1006/meth.2001.1262

PMid:11846609

27. Brandt N, de Bock K, Richter EA, Hespel P. Cafeteria diet-induced insulin resistance is not associated with decreased insulin signaling or AMPK activity and is alleviated by physical training in rats. Am J Physiol Endocrinol Metab. 2010;299(2):E215-24. https://doi.org/10.1152/ajpendo.00098.2010 PMid:20484011

28. Carling D, Mayer FV, Sanders MJ, Gamblin SJ. AMPK-activated protein kinase: Nature's energy sensor. Nat Chem Biol. 2011;7(8):512-8. https://doi.org/10.1038/nchembio.610 PMid:21769098

29. Viollet B, Foretz M, Guigas B, Horman S, Dentin R, Bertrand L, et al. Activation of AMP-activated protein kinase in the liver: A new strategy for the management of metabolic hepatic disorders. J Physiol. 2006;574(1):41-53.

30. Machrina Y, Pane YS, Lindarto D. The expression of liver metabolic enzymes ampk $\alpha 1$, ampk $\alpha 2$, and pgc- $1 \alpha$ due to exercise in Type-2 diabetes mellitus rat model. Open Access Maced J Med Sci. 2020;8:629-32.

31. Thomson DM. The role of AMPK in the regulation of skeletal muscle size, hypertrophy, and regeneration. Int J Mol Sci. 2018;19(10):3125. https://doi.org/10.3390/ijms19103125 PMid:30314396

32. Torma F, Gombos Z, Jokai M, Takeda M, Mimura T, Radak Z. High intensity interval training and molecular adaptive response of skeletal muscle. Sport Med Health Sci. 2019;1(1):24-32.

33. Combes A, Dekerle J, Webborn N, Watt P, Bougault V, Daussin FN. Exercise-induced metabolic fluctuations influence AMPK, p38-MAPK and CaMKII phosphorylation in human skeletal muscle. Physiol Rep. 2015;3(9):e12462. https://doi. org/10.14814/phy2.12462

PMid:26359238

34. DeFronzo RA, Tripathy D. Skeletal muscle insulin resistance is the primary defect in Type 2 diabetes. Diabetes Care. 2009;32 Suppl 2:S157-63. https://doi.org/10.2337/dc09-S302 PMid:19875544

35. Gutierrez-Rodelo C, Roura-Guiberna A, Olivares-Reyes JA. Molecular mechanisms of insulin resistance: An update. Gac Med Mex. 2017;153:197-209.

PMid:28474708

36. Lehnen AM. Changes in the GLUT4 expression by acute exercise, exercise training and detraining in experimental models. J Diabetes Metab. 2013;1(10):1-8.

37. Ojuka EO, Goyaram V, Smith JA. The role of CaMKII in regulating GLUT4 expression in skeletal muscle. Am J Physiol Endocrinol Metab. 2012;303(3):322-31. https://doi.org/10.1152/ ajpendo.00091.2012

PMid:22496345

38. Ling C, Roon T, Nitert MD. Epigenetics and Type-2 Diabetes in Epigenetics Aspect of Chronic Diseases. Berlin, Germany: Springer; 2011. p. 135-45.

39. Koh JH, Hancock CR, Han DH, Holloszy JO, Nair KS, Dasari S. AMPK and PPAR $\beta$ positive feedback loop regulates endurance exercise training-mediated GLUT4 expression in skeletal muscle. Am J Physiol Endocrinol Metab. 2019;316(5):E931-9. https://doi.org/10.1152/ajpendo.00460.2018 PMid:30888859

40. Machrina Y, Purba A, Lindarto D, Maskoen AM. Exercise intensity alter insulin receptor gene expression in diabetic Type-2 rat model. Open Access Maced J Med Sci. 2019;7(20):3370-5. https://doi.org/10.3889/oamjms.2019.425

PMid:32002053 